\title{
Secretory function of adipose tissue
}

\author{
J. Kuryszko ${ }^{1}$, P. Stawuta², G. Sapikowski \\ ${ }^{1}$ Department of Animal Physiology and Biostructure, Histology and Embryology Unit, \\ Faculty of Veterinary Medicine, Wroclaw University of Environmental and Life Sciences, \\ Norwida 31, 50-375 Wrocław \\ ${ }^{2}$ Department of Internal Diseases, Faculty of Veterinary Medicine, \\ Wroclaw University of Environmental and Life Sciences, pl. Grunwaldzki 47, 50-366 Wrocław
}

\begin{abstract}
There are two kinds of adipose tissue in mammals: white adipose tissue - WAT and brown adipose tissue - BAT. The main function of WAT is accumulation of triacylglycerols whereas the function of BAT is heat generation. At present, WAT is also considered to be an endocrine gland that produces bioactive adipokines, which take part in glucose and lipid metabolism. Considering its endocrine function, the adipose tissue is not a homogeneous gland but a group of a few glands which act differently. Studies on the secretory function of WAT began in 1994 after discovery of leptin known as the satiation hormone, which regulates body energy homeostasis and maintainence of body mass. Apart from leptin, the following belong to adipokines: adiponectin, resistin, apelin, visfatin and cytokines: TNF and IL 6. Adiponectin is a polypeptide hormone of antidiabetic, anti-inflammatory and anti-atherogenic activity. It plays a key role in carbohydrate and fat metabolism. Resistin exerts a counter effect compared to adiponectin and its physiological role is to maintain fasting glycaemia. Visfatin stimulates insulin secretion and increases insulin sensitivity and glucose uptake by muscle cells and adipocytes. Apelin probably increases the insulin sensitivity of tissues. TNF evokes insulin resistance by blocking insulin receptors and inhibits insulin secretion. Approximately $30 \%$ of circulating IL 6 comes from adipose tissue. It causes insulin resistance by decreasing the expression of insulin receptors, decreases adipogenesis and adiponectin and visfatin secretion, and stimulates hepatic gluconeogenesis. In 2004, Bays introduced the notion of adiposopathy, defined as dysfunction of the adipose tissue, whose main feature is insulin and leptin resistance as well as the production of inflammatory cytokines: TNF and IL 6 and monocyte chemoattractant protein. This means that excess of adipose tissue, especially visceral adipose tissue, leads to the development of a chronic subclinical inflammatory condition, which favours the development of insulin resistance and Type 2 diabetes. Obesity is a systemic illness caused by energy transformation homeostasis disorder which results in an increase in the amount of body fat mass. It effects approximately $40 \%$ of dogs and $20 \%$ of cats. Illnesses which accompany obesity result, to a great extent, from the secretive role of adipose tissue, which is still little known, which should be included when planning treatment of an obese animal.
\end{abstract}

Key words: adipose tissue, insulin resistance, adipokines 
There are two kinds of adipose tissue in mammals: white adipose tissue (WAT) and brown adipose tissue (BAT). There are differences between WAT and BAT in their structure and functions regarding the way in which triacylglycerols are accumulated, the shape and number of mitochondria, the presence of adrenergic nerve endings, and vascularity. In general, it is assumed that the main function of WAT is accumulation of an energy substrate in the form of triacylglycerols whereas the function of BAT is heat generation (Wójcik and Górski 2011).

Nowadays, WAT is not perceived solely as an energy storage reservoir and source but is also considered to be an endocrine gland that produces hormones and bioactive substances called adipokines. Adipokines take part in glucose and lipid metabolism, body's immune response, and are often the cause of obesity-related diseases (Cancello et al. 2004). Considering its endocrine function, the adipose tissue is not a homogeneous gland but a group of a few glands which act differently. In the visceral adipose tissue, secretion of interleukin-6 (IL 6), Tumor Necrosis Factor (TNF), and resistin and visfatin higher than in the subcutaneous adipose tissue are observed, whereas in the subcutaneous adipose tissue, higher concentrations of leptin and adiponectin occur (Kershaw and Flier 2004). It is also important that the visceral adipose tissue secretes substances directly to the portal vein from where they directly reach the liver and have impact on it's function - cytokines released to the liver increase concentration of C Reactive Protein and contribute to hepatic steatosis. The subcutaneous adipose tissue releases leptin and adiponectin to the systemic circulation (Heilbrom et al. 2004, Nedergaad et al. 2005). The studies on the secretory function of the white adipose tissue began in 1994 as a result of discovery of leptin, a hormone produced by mature adipocytes (Zhang et al. 1994). Leptin is sometimes called the satiation hormone, which regulates body energy homeostasis and maintaining of body mass (in Greek leptos means thin, slim). It is protein with a mass of $16.7 \mathrm{kDa}$ created in the mature white adipose tissue. Its biosynthesis and secretion depend on the mass of a body fat and reflect the content of energy resources of an organism. The main factors which have an impact on secretion of the hormone are sizes of adipocytes and mass of the adipose tissue. Concentration of leptin in blood serum in obese individuals is higher but leptin resistance occurs and even administration of exogenous leptin does not reduce body mass (Hukshorn and Saris 2004, Meier and Gressner 2004). Small amounts are also secreted by the placenta, brain, stomach, and mammary gland, and in the liver in birds (Masuzaki et al. 1997, Bado et al. 1998). Leptin biosynthesis is stimulated by insulin, glucose, corticosteroids, large amounts of fat and carbohydrates in the diet, and regular meals. Secretion of the hormone is hampered by glucagon, catecholamines and low temperature (Konner et al. 2009). It is also known that leptin release is subject to day and night rhythm in humans - it is low during the day and increases at night, which is explained as an effect of not eating (Sinha et al.1996).

Leptin regulates the metabolism of an organism via the central and peripheral nervous system (Fig. 1). Via the central nervous system, it takes part, as an anorexigenic protein factor, in the regulation of food intake by acting on the hypothalamus where it inhibits secretion of neuropeptide $\mathrm{Y}$ and Agouti-related protein, which stimulate appetite. Leptin in the hypothalamus also stimulates the POMC (proopiomelanocortin) system and CARD system (a protein whose transcription is stimulated by cocaine, amphetamine, and corticotropin-releasing hormones), which inhibit appetite, reduce the mass of the adipose tissue and increase the amount of energy expenditure which results in the loss of body mass (Wiesner et al. 1999, Hukshorn et al. 2004, Meier and Gressner 2004). Via the peripheral nervous system, leptin regulates the metabolism of an organism through inhibition of lipogenesis, stimulation of lipose, and an increase of oxidation of fatty acids (by stimulating their $\beta$-oxidation). The influence of leptin on glucose transformation is still not fully understood and it is now thought that leptin increases glycolysis and the insulin sensitivity of tissues and inhibits hepatic gluconeogenesis. Leptin also stimulates the growth of cancer cells (Horiguchi et al. 2006, Wiwanitkit 2007).

When discussing the biological role of leptin, its counterpart ghrelin should be mentioned. Ghrelin was discovered in 1999 and most of it i.e. approximately $70 \%$ is released from the parietal cells of the glands of the body and the fundus of the stomach (Date et al. 2000, Muccioli et al. 2002, Greenman et al. 2004); the rest of it is released in the intestines, the pituitary gland, and the hypothalamus. Leptin is also secreted by cancer cells (Date et al. 2000). Its most important function, however, is to stimulate secretion of the growth hormone but it is also the only hormone acting in the central nervous system which stimulates appetite and inhibits proliferation of breast and prostate cancer cells (Inui et al. 2004).

Apart from leptin, there are other adipokines whose role is still being studied such as: adiponectin, resistin, apelin, visfatin and the cytokines: TNF i.e. a tumour necrosis factor and interleukin-6 (IL 6) (Trayhurn and Wood 2004, Tilg and Moschen 2006).

Adiponectin is a polypeptide hormone with a mass of $33 \mathrm{kDa}$ secreted by adipose cells and it has an anti- 


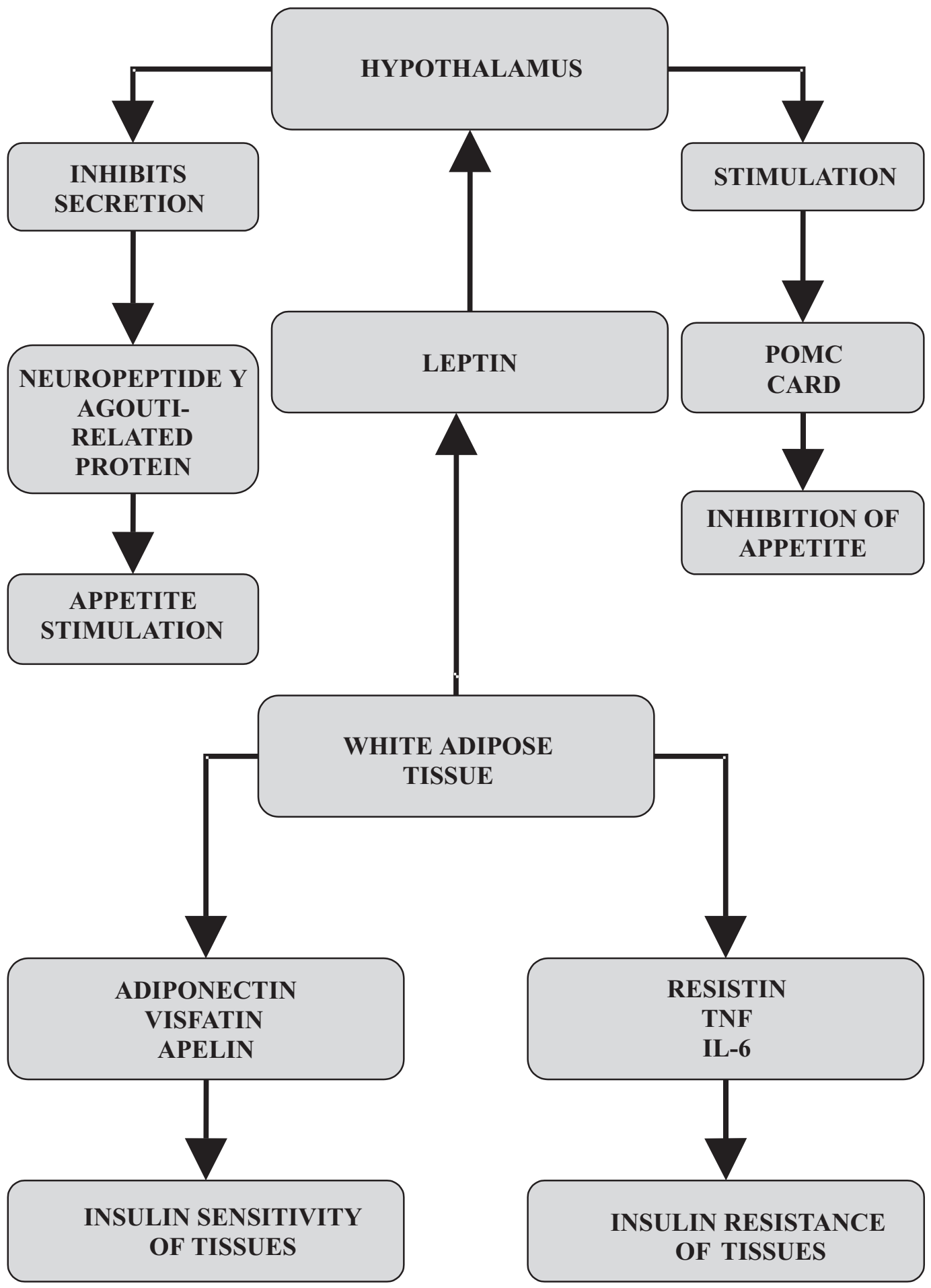

Fig. 1. Schematic of leptin activity.

diabetic, anti-inflammatory and anti-atherogenic function (Cummings and Schwartz 2003, Haluzik et al. 2004). It plays a key role in carbohydrate and fat metabolism. Its secretion is stimulated by insulin and inhibited by TNF and IL- 6 . Secretion of the hormone increases with reduction of body mass and decreases in the case of obesity (Żurawska and Drzeworski
2004, Kadowski and Yamauchi 2005). Adiponectin increases insulin sensitivity of tissues, stimulates muscle glucose uptake and inhibits hepatic gluconeogenesis, and decreases the concentration of free fatty acids by increasing oxidation. It is anti-atherogenic and anti-inflammatory to the capillary endothelium. It is an antagonist of receptor IL 1 and it stimulates 
secretion of IL 10 (Kadowski and Yamauchi 2005, Kozłowska and Kowalska 2006). It is known that adiponectin acts in the same way in humans and cats, which indicates why, as in humans, insulin resistance and Type 2 diabetes occur in cats (yet it occurs very rarely in dogs) (Prostek et al. 2014).

Resistin is a peptide with a mass of $12 \mathrm{kDa}$ produced by adipocytes and macrophages which exerts a counter effect compared to adiponectin (Banerjee and Lazar 2003). Its physiological role is to maintain fasting glycaemia and the effect of its action is formation of an excess amount of white adipose tissue (Steppan et al. 2001). Resistin activates gluconeogenesis, increases glycogenolysis and insulin resistance, and acts as a proinflammatory factor by increasing production of TNF, IL 1, IL 6, and IL 12 (Skowrońska and al. 2005).

Visfatin stimulates insulin secretion and increases insulin sensitivity and glucose uptake by muscle cells and adipocytes. It also has a strong proinflammatory function and activates leukocytes and cytokines and increases adiposeness (Fukuhara et al. 2005).

Apelin probably increases the insulin sensitivity of tissues. Hunger is a factor that inhibits secretion of apelin and, as like in the case of insulin, its concentration increases after a meal (Boucher et al. 2005).

Nowadays, it is also thought that active brown adipose tissue may prevent obesity and insulin resistance (Cinti 2011, Wójcik and Górski 2011).

In 2004, Bays (2004) introduced the notion of adiposopathy defined as dysfunction of the adipose tissue, whose main feature is insulin and leptin resistance as well as the production of the inflammatory cytokines TNF and IL 6, and monocyte chemoattractant protein (Bays 2004). This means that excess of adipose tissue, especially visceral adipose tissue, leads to the development of a chronic subclinical inflammatory condition, which favours the development of insulin resistance and Type 2 diabetes (Siemińska 2007). There is a theory which assumes that the inflammatory reaction in obesity is a mechanism which protects the organism from reaching the point at which excess accumulation of fat impairs the possibility of movement. Accumulation of lipids and adipose tissue is a typical anabolic process stimulated by insulin, whereas release of cytokines is said to start an inflammatory process which initiates catabolic processes resulting in release of lipids and an attempt to inhibit further increase in body mass (Xu et al. 2002). It is still not known for certain what initiates the inflammatory reaction and it is now assumed that there are three most likely causes:

1) the inflammatory reaction is in the adipose tissue in response to adipocyte hypoxia - an increasing fat cell moves away from blood vessels and hypoxia causes the release of IL 6 (Trayhurn et al. 2008).

2) oxidative stress caused by on increased supply of glucose to the fat cells. Sugar is taken up by endothelium cells of the stroma vessels and increases the production of free radicals in them which damages the cells by triggering an inflammatory reaction (Lin et al. 2005)

3) cell stress theory, which assumes that adipocyte hypertrophy contributes to the impairment of the functions of the endoplasmic reticulum and the activation of stress-sensitive proteins which occur in it (Persegin et al 2003).

TNF within the adipose tissue is secreted by adipocytes and stromal cells and is responsible for causing insulin resistance by blocking the receptors for this hormone, and has an impact on pancreatic beta cells inhibiting insulin secretion (Liu 1998). In a fat cell, TNF inhibits its ability to estrificate fatty acids, decreases secretion of adiponectine, and inhibits the transport of glucose to the liver cells and fatty acid oxidation. Approximately $30 \%$ of the circulating IL-6 comes from the adipose tissue, and synthesis in the visceral adipose tissue is about three times higher than in the subcutaneous adipose tissue. High concentrations of this cytokine cause insulin resistance - IL-6 decreases expression of insulin receptors, decreases adipogenesis and secretion of adiponectin and visfatin, and stimulates liver gluconeogenesis. It is not yet known exactly how the above-mentioned cytokines block insulin receptors and insulin signal transmission (Kern et al 2001, Ruan and Lodish 2003).

Obesity is a systemic illness caused by energy transformation homeostasis disorder, which results in an increase in the amount of body fat mass above the accepted norm. It occurs as a result of excess filling in of already existing adipose cells with triacylglycerols (hypertrophy) or formation of new ones (hyperplasia) or both phenomena at the same time. Obesity results from a positive energy balance and affects more and more pet animals. According to different authors, dogs and cats with excess body mass constitute approximately $40 \%$ and $20 \%$, respectively, of the population in highly-developed countries. The reasons for this phenomenon is, as usual, identical with humans i.e. too high amount of energy supplied, too little physical activity, and nutrition factors related to frequent consumption of snacks. Of course, there are also reasons typical for animals only, such as castration or breed predispositions. Obesity therapy consists in achieving a negative energy balance as a result of a complex dietary treatment combined with physical activity. A study on the possibility of transdifferentiation of adipocytes and a clinical use of this phenomenon is now in progress. It is thought that detailed 
knowledge of mechanisms and the working out of a technique for increasing the number of BAT cells at the cost of WAT cells would be an unusually effective weapon for fighting obesity and insulin resistance. It is also worth mentioning that removal of subcutaneous adipose tissue (liposuction), which is a recent trend among people, causes growth of the visceral adipose tissue, a build-up of fat in the liver, and an increase of insulin resistance as the production of cytokines does not change (Perseghin et al. 2003).

Excess accumulation of adipose tissue causes illnesses associated with insulin resistance, especially diabetes in cats and osteoarthritis. Illnesses which accompany obesity result from the secretive role of adipose tissue, which is still little known, and which should be included in the planning of treatment for an obese animal (Prostek et al 2014).

\section{References}

Bado A, Levasseur S, Attoub S, Kermorgant S, Laigneau JP, Bortoluzzi MN, Moizo L, Lehy T, Guerre-Millo M, Le Marchand-Brustel Y, Lewin MJ (1998) The stomach is a source of leptin. Nature 394: 790-793.

Banerjee RR, Lazar MA (2003) Resistin: molecular history and prognosis $\mathrm{J}$ Mol Med (Berl) 81: 218-226.

Bays HE (2004) Current and investigational antiobesity agents and obesity therapeutic treatment targets. Obes Res 12: 1197-1211.

Boucher J, Masri B, Daviaud D, Gesta S, Guigné C, Mazzucotelli A, Castan-Laurell I, Tack I, Knibiehler B, Carpéné C, Audigier Y, Saulnier-Blache JS, Valet $\mathrm{P}$ (2005) Apelin, a newly identified adipokine up-regulated by insulin and obesity. Endocrinology 146: 1764-1771.

Cancello R, Tounian A, Poitou Ch, Clement K (2004) Adiposity signals, genetic and body weight regulation in humans. Diabetes Metab 30: 215-227.

Cinti S (2011) Between brown and white: novel aspects of adipocyte differentiation. Ann Med 43: 104-115.

Cummings DE, Schwartz MW (2003) Genetics and pathophysiology of human obesity. Annu Rev Med 54: 453-471.

Date Y, Kojima M, Hosoda H, Sawaguchi A, Mondal MS, Suganuma T, Matsukura S, Kangawa K, Nakazato M (2000) Ghrelin, a novel growth hormone-releasing acylated peptide, is synthesized in a distinct endocrine cell type in the gastrointestinal tracts of rats and humans. Endocrinology 141: 4255-4261.

Fukuhara A, Matsuda M, Nishizawa M, Segawa K, Tanaka M, Kishimoto K, Matsuki Y, Murakami M, Ichisaka T, Murakami H, Watanabe E, Takagi T, Akiyoshi M, Ohtsubo T, Kihara S, Yamashita S, Makishima M, Funahashi T, Yamanaka S, Hiramatsu R, Matsuzawa Y, Shimomura I (2005) Visfatin: a protein secreted by visceral fat that mimics the effects of insulin. Science 307: 426-430.

Greenman Y, Golani N, Gilad S, Yaron M, Limor R, Stern $\mathrm{N}$ (2004) Ghrelin secretion is modulated in a nutrientand gender-specific manner. Clin Endocrinol (Oxf) 60: $382-388$
Haluzik M, Partzková J, Haluztk MM (2004) Adiponectin and its role in the obesity-induced insulin resistance and related complications. Physiol Res 53: 123-129.

Heilbronn L, Smith SR, Ravussin E (2004) Failure of fat cell proliferation, mitochondrial function and fat oxidation results in ectopic fat storage, insulin resistance and type II diabetes mellitus. Int J Obes Relat Metab Disord 28 (Supll 4): S12-S21.

Horiguchi A, Sumitomo M, Asakuma J, Asano T, Zheng R, Asano T, Nanus DM, Hayakawa M (2006) Increased serum leptin levels and over expression of leptin receptors are associated with the invasion and progression of renal cell carcinoma. J Urol 176: 1631-1635.

Hukshorn CJ, Saris WH (2004) Leptin and energy expenditure. Curr Opin Clin Nutr Metab Care 7: 629-633.

Hukshorn CJ, Lindeman JH, Toet KH, Saris WH, Eilers PH, Westerterp-Plantenga MS, Kooistra T (2004) Leptin and the proinflammatory state associated with human obesity. J Clin Endocrinol Metab 89: 1773-1778

Inui A, Asakawa A, Bowers CY, Mantovani G, Laviano A, Meguid MM, Fujimiya M (2004) Ghrelin, appetite, and gastric motility: the emerging role of the stomach as an endocrine organ. FASEB J 18: 439-456.

Kadowaki T, Yamauchi T (2005) Adiponectin and adiponectin receptors. Endocr Rev 26: 439-451.

Kern PA, Ranganathan S, Li C, Wood L, Ranganathan $G$ (2001) Adipose tissue tumor necrosis factor and interleukin- 6 expression in human obesity and insulin resistance. Am J Physiol Endocrinol Metab 280: E745-E751.

Kershaw EE, Flier JS (2004) Adipose tissue as an endocrine organ. J Clin Endocrinol Metab 89: 2548-2556.

Kozłowska A, Kowalska I (2006) The adiponectin role in pathogenesis of metabolic syndrome and cardiovascular disease. Endocrinol Pol 57: 626-632.

Könner AC, Klöckener T, Brüning JC (2009) Control of energy homeostasis by insulin and leptin: targeting the arcuate nucleus and beyond. Physiol Behav 97: 632-638.

Lin Y, Berg AH, Iyengar P, Lam TK, Giacca A, Combs TP, Rajala MW, Du X, Rollman B, Li W, Hawkins M, Barzilai N, Rhodes CJ, Fantus IG, Brownlee M, Scherer PE (2005) The hyperglycemia-induced inflammatory response in adipocytes: the role of reactive oxygen species. J Biol Chem 280: 4617-4626.

Liu LS, Spelleken M, Rohrig K, Hauner H, Eckel J (1998) Tumor necrosis factor-alpha acutely inhibits insulin signaling in human adipocytes: implication of the p80 tumor necrosis factor receptor. Diabetes 47: 515-522.

Masuzaki H, Ogawa Y, Sagawa N, Hosoda K, Matsumoto T, Mise H, Nishimura H, Yoshimasa Y, Tanaka I, Mori T, Nakao K (1997) Nonadipose tissue production of leptin: leptin as a novel placenta-derived hormone in humans. Nat Med 3: 1029-1033.

Meier U, Gressner AM (2004) Endocrine regulation of energy metabolism: review of pathobiochemical and clinical chemical aspects of leptin, ghrelin, adiponectin, and resistin. Clin Chem 50: 1511-1525.

Muccioli G, Tschöp M, Papotti M, Deghenghi R, Heiman M, Ghigo E (2002) Neuroendocrine and peripheral activities of ghrelin: implications in metabolism and obesity. Eur J Pharmacol 440: 235-254.

Nedergaard J, Petrovic N, Lindgren EM, Jacobsson A, Cannon B (2005) PPARgamma in the control of brown adipocyte differentiation. Biochim Biophys Acta 1740: 293-304. 
Perseghin G, Petersen K, Shulman GI (2003) Cellular mechanism of insulin resistance: potential links with inflammation. Int J Obes Relat Metab Disord 27 (Supll 3): S6-S11

Prostek A, Kamola D, Kosińska H, Bałaśińska B (2014) Adipose tissue inflammation accompanying obesity in dogs and cats. Życie Weterynaryjne 89: 133-136.

Ruan H, Lodish HF (2003) Insulin resistance in adipose tissue: direct and indirect effects of tumor necrosis factor-alpha. Cytokine Growth Factor Rev 14: 447-455.

Skowrońska B, Fichna M, Fichna P (2005) The role of adipose tissue in endocrine system Otyłość i Zaburzenia Przemiany Materii 1: 21-29.

Siemińska L (2007) Adipose tissue. Pathophysiology, distribution, sex differences and the role in inflammation and cancerogenesis. Endocrinol Pol 58: 330-342.

Sinha MK, Ohannesian JP, Heiman ML, Kriauciunas A, Stephens TW, Magosin S, Marco C, Caro JF (1996) Nocturnal rise of leptin in lean, obese, and non-insulin-dependent diabetes mellitus subjects. J Clin Invest 97: $1344-1347$

Sławuta P (2011) Diet and body weight loss. Weterynaria w Praktyce 3: 70-74

Steppan CM, Bailey ST, Bhat S, Brown EJ, Banerjee RR, Wright CM, Patel HR, Ahima RS, Lazar MA (2001) The hormone resistin links obesity to diabetes. Nature 409: 307-312
Tilg H, Moschen AR (2006) Adipocytokines mediators linking adipose tissue, inflammation and immunity. Nat Rev Immunol 6: 772-783.

Trayhurn P, Wang B, Wood IS (2008) Hypoxia in adipose tissue: a basis for the dysregulation of tissue function in obesity? Br J Nutr 100: 227-235

Trayhurn P, Wood IS (2004) Adipokines: inflammation and the pleiotropic role of white adipose tissue. Br J Nutr 92: 347-355.

Wiesner G, Vaz M, Collier G, Seals D, Kaye D, Jennings G, Lambert G, Wilkinson D, Esler M (1999) Leptin is released from the human brain: influence of adiposity and gender. J Clin Endocrinol Metab 84: 2270-2274.

Wiwanitkit V (2007) Interaction between leptin and leptin receptor in gastric carcinoma: gene ontology analysis. Rev Esp Enferm Dig 99: 201-205.

Wójcik B, Górski J (2011) Brown adipose tissue in adult humans: distribution and function. Endokrynologia, Otyłość i Zaburzenia Przemiany Materii 7: 34-40.

Xu H, Hirosumi J, Uysal KT, Guler AD, Hotamisligil GS (2002) Exclusive action of transmembrane TNF alpha in adipose tissue leads to reduced adipose mass and local but not systemic insulin resistance. Endocrinology 143: 1502-1511.

Zhang Y, Proenca R, Maffei M, Barone M, Leopold L, Friedman JM (1994) Positional cloning of the mouse obese gene and its human homologue. Nature 372: 425-432. 